\title{
Temporal and Spatial Variations of Eocene-Oligocene Ignimbrite Flare- Up Volcanism in South New Mexico
}

\author{
KARISSA B. VERMILLION ${ }^{*}$, EMILY R. JOHNSON', JAKE I \\ ROSS $^{2}, \&$ JEFFREY M. AMATO' \\ Dept. of Geological Sciences, New Mexico State University, \\ Las Cruces, NM 88003 (*correspondence: \\ kbvrmlln@nmsu.edu) \\ 2New Mexico Bureau of Geology and Mineral Resources, \\ Socorro, New Mexico 87801.jake.ross@nmt.edu
}

The Paleogene ignimbrite flare-up spanned Nevada to Texas, and into Mexico and is characterized by widespread silicic caldera-forming eruptions. Deposits include intracaldera fill and outflow sheets and correlations between the two can be extremely difficult. In southern New Mexico, the ignimbrite flare-up generated the Mogollon-Datil (MDVF) and Boot Heel (BHVF) volcanic fields between 36-21 Ma. Past workers [1] have proposed NNW migration in volcanism over time coincident with rollback of the Farallon slab. However, recently [2] it was noted that there was more complex migration of caldera volcanism. Here, new high-precision single crystal laser fusion ${ }^{{ }^{\circ} \mathrm{Ar} /{ }^{\circ} \mathrm{Ar}}$ geochronology and feldspar geochemistry provide insight into outflow sheet correlation and temporal-spatial variations of magmatism.

Preliminary results suggest that the initiation of caldera volcansim occurred over a broad region $(\sim 240 \mathrm{~km})$ of southern New Mexico at $236.5-35.0 \mathrm{Ma}$, and volcanism during this episode continued through $33.0 \mathrm{Ma}$. Within the 35.5-35.3 Ma window, there were at least four major calderaforming eruptions. Results thus far do not support a sequential westward migration of volcanism as previously proposed. These results have important implications for tectonic models of slab rollback and resulting volcanism.

Feldspar major and trace element geochemistry was obtained from the same samples to correlate tuffs and examine changes in magma geochemistry. Combining our geochronology and geochemistry data, we have successfully correlated previously uncorrelated tuffs across the MDVF. We also find that most ignimbrites older than $34.5 \mathrm{Ma}$ are crystal poor whereas younger units are predominantly crystal rich. These findings may have implications for large-scale magma processing in slab rollback tectonic environments.

[1] Chapin et al. (2004), The Geology of New Mexico, A Geologic History, NMGS, 271-293. [2] Ricketts et al. (2016), GSA Bulletin 128, 397-424. 